\title{
ТЕХНОЛОГИЯ МАСТЕРСТВА
}

УДК 78.07

doi: 10.17223/26188929/8/5

\author{
Виталий Максимов
}

\section{ТЬЮТОРСКОЕ СОПРОВОЖДЕНИЕ В ОБУЧЕНИИ СТУДЕНТА-ПИАНИСТА}

\begin{abstract}
В статье излагается сущность тьюторского сопровождения в учебном процессе, даются конкретные рекомендации для педагога-тьютора в обучении студентов-пианистов. Утверждается, что тьютор должен быть настоящим авторитетом для студента, хорошо понимать и чувствовать свойства его психики, пользоваться неограниченным доверием у студента. В тьюторской работе необходима, как нигде, психологическая совместимость тьютора и студента. Кроме того, вопрос выбора репертуара должен решаться с помощью тьютора.
\end{abstract}

Ключевые слова: тьюторство, развитие индивидуальных способностей студента, психологическая совместимость тьютора и студента.

Тьютор - с английского «опекун», «наставник».

Тьюторское сопровождение - это прогрессивное направление в современной мировой педагогике [2].

Чаще всего на занятиях со студентами идет процесс передачи профессиональных советов, исполнительского опыта педагога учащемуся [1]. Этого, конечно, недостаточно. Необходимо выявлять все положительные качества студента, поощрять их развитие, раскрытие индивидуальности... Это все задачи тьютора.

Как правило, студент не видит себя в перспективе: кем он будет, какой род деятельности будет для него основным. Лишь немногие студенты-музыканты обещают быть в дальнейшем солистами. Из пианистов чаще всего могут вырасти неплохие аккомпаниаторы. Тьютор обязан уже на раннем этапе обучения распознать, в каком направлении следует развивать способности и склонности студента. И не только распознать, но и всячески поощрять индивидуальные способности. Так, будущий аккомпаниатор должен иметь возмож- 
ность чаще выступать в концертах именно в этом качестве. Тьюторское сопровождение должно помочь раскрывать свои индивидуальные способности. Это не отменяет, конечно, кропотливой работы над сугубо профессиональными исполнительскими проблемами.

Так как на практике затруднительно каждому студенту иметь своего тьютора, каждый педагог должен четко осознавать, что он же осуществляет и тьюторское сопровождение вместе с собственно педагогическим процессом.

Это накладывает на педагога большую ответственность - надо одновременно владеть мастерством игры на инструменте, быть прекрасным, чутким психологом, осознавать ответственность за будущее ученика. Это сложно, но необходимо.

Дидактический принцип развивающего обучения успешно реализуется в такой форме работы студента-музыканта, как эскизная работа над музыкальным произведением.

В эскизной работе студенту, конечно, нужна помощь тьютора. Тьютор должен рекомендовать список нужных произведений, желательно разностильных, разных авторов, чтобы студент получил максимум ярких впечатлений познавательного характера.

Процесс эскизной работы должен носить творческий характер, протекать живо, ярко и увлеченно.

Эскизная работа немыслима без навыка чтения музыки «с листа». Здесь задача тьютора обеспечить правильный подход к чтению текста.

Практически любой исполнитель перед выходом на сцену испытывает волнение, зачастую разрушительное. Тьютор должен и здесь помочь, внушить студенту, что волноваться надо не за себя, а за композитора. На сцене надо сосредоточиться на процессе игры.

Опытный тьютор подскажет ученику приемы аутотренинга (правильное дыхание и расслабленность мышц). Помимо специального предмета у студентов-пианистов есть важный предмет камерный ансамбль. Тьютор должен помочь подобрать участников ансамбля. Внутри ансамбля необходимо создать доброжелательную атмосферу и благоприятный психологический климат.

Непростой вопрос выбора репертуара должен решаться с помощью тьютора.

В тьюторской работе, на наш взгляд, необходима психологическая совместимость тьютора и студента. Без этого тьюторская работа будет затруднительной и, может быть, обречена на провал. 
Тьютор должен быть настоящим авторитетом для студента, хорошо понимать и чувствовать свойства его психики, пользоваться неограниченным доверием у студента. Только при этом условии тьюторское сопровождение будет эффективным.

\section{Использованные источники}

1. Цыпин Г.М. Обучение игре на фортепиано. М. : Просвещение, 1984.

2. Цыпин Г.М. Психология музыкальной деятельности. М. : Интерпракс, 1994.

\section{Vitaly Maximov}

\section{TUTORING IN TRAINING OF A STUDENT PIANIST}

Musical almanac of Tomsk State University, 2019, no. 8, pp. 27-29. doi: $0.17223 / 26188929 / 8 / 5$

Tutoring is a progressive direction in modern world pedagogy.

Most often in the classroom there is a process of transferring advice, performing experience of the teacher to the student, but this is not sufficient. It is necessary to reveal all merits of student, to encourage his development, disclosure the identity.... All this is a tutor's tasks. As in practice, it is difficult to each student to have a tutor the teacher has to realize clearly that he carries out also tutoring maintenance together with the pedagogical process.

It imposes a big responsibility on the teacher - it is necessary at the same time to own skills of a playing an instrument, to be a great, sensitive psychologist, to have responsibility for the future of the student. It is difficult, but it is necessary. Practically, any performer, before going to the stage, experiences nervousness, often destructive. The tutor has to help, inspire the student that he has to worry not for himself, but for the composer. On the stage it is necessary to focus on the process of play.

The experienced tutor will prompt to the student methods of auto training (the correct breath and muscle relaxation). Except for a special subject, students have an important subject - chamber ensemble. The tutor has to help to choose participants of the ensemble and to create a friendly atmosphere and favorable psychological climate.

The difficult issue of the choice of the repertoire must be resolved with help of the tutor. In tutoring it is necessary, in our opinion, as perhaps nowhere, the psychological compatibility of the tutor and the student ${ }^{1}$.

Keywords: Tutoring, development of individual abilities of the student, psychological compatibility of the tutor and student.

\section{The used sources}

1. Cypin G.M. Obuchenie igre na fortepiano[Piano training]. M.: Prosveshchenie, 1984

2. Cypin G.M. Psihologiya muzykal'noj deyatel'nosti [Psychology of music]. M.: Interpraks, 1994.

${ }^{1}$ Перевод Т.Ф. Шестаковой. 